\title{
IS THE USE OF VIDEO FOOTAGE DURING INDUSTRIAL ACTION A SOLUTION TO LIABILITY FOR COLLECTIVE MISCONDUCT? - PART 1
}

\author{
Mlungisi Tenza \\ LLB LLM \\ Lecturer, University of KwaZulu-Natal
}

\section{SUMMARY}

The issue of strikes turning violent has been a hot potato in industrial relations in South Africa. Strikers vandalise property and sometimes harm innocent people or members of the public. It has been difficult to hold liable either the convening union or individual members involved in the commission of such acts. Unions often deny liability for damage caused under these circumstances and deny having relations with those involved in the commission of such acts. It is also difficult for victims of violent industrial action to hold all participants liable for the damage caused. The article recommends that assistance needs to be sought from the CCTV cameras. The footage captured by these cameras should be used to show exactly who committed the conduct complained of. If a person is identified through CCTV footage as the one who committed the unlawful act and such person being linked to the convening union, the union should account for such conduct. Unions are assumed to be in control of the movement of strikers when it is pending. It should be held liable on the ground that it is expected to take certain measures or reasonable steps to prevent violent acts by its members. Victims of such conduct would then have an action and a claim for remedies against the union. However, the union can have recourse against responsible members. The remedies available to victims include an application for an interdict, a claim for a just and equitable compensation and dismissal provided a fair procedure has been followed.

\section{INTRODUCTION}

Unions often deny liability for the conduct of members during a picket or protest action on the grounds that the people who committed unlawful acts or misconduct were not their members. By so doing, the implication is that unions would take responsibility if it could be proved that it was indeed their members who committed the unlawful acts. The nature of industrial action makes it easy for unions denying liability for damage caused. The collective nature of industrial action makes it difficult for the victims of industrial action to identify the actual perpetrator(s) of wrongful acts and link them to the convening union. Eyewitnesses are also reluctant to give evidence on whom actually committed the act during a collective action. 
If it is difficult to identify a particular perpetrator as a member(s) of the union, it may be unfair to attempt to hold a union liable for the conduct committed by people who are not its members. In addition, there is no established legal rule that holds unions liable for the conduct of members during industrial action. The article submits that it would be advisable if the actual perpetrator(s) ${ }^{1}$ can be identified where groups of people were involved in the activity that resulted in the commission of the unlawful act(s). The identification of the actual perpetrator will help to protect innocent participants in a picket or protest from being held liable for the conduct of others, or acts they never committed. It will also serve to counter union denials that the people involved in the commission of unlawful acts during industrial action were not their members. In addition, the identification of actual perpetrators will help to exempt the union from liability for conduct committed by people who are not its members.

The article proposes the use of Closed Circuit Television (CCTV) cameras to help identify the actual perpetrator and the identified individual should account for his or her conduct. ${ }^{2}$ However, the union (with certain exceptions) should be held liable if video footage proves that the people who committed the unlawful acts were its members. The claimant will have a choice whether he or she wants to hold the union liable, or the individual member. This contribution will be limited to the investigation of using CCTV footage to identify individual members liable and the consequences that should follow. Part 2 of this series will detail how a union can be held liable for the conduct of its members.

\section{BACKGROUND}

It is common knowledge that workers commit a variety of unlawful acts during industrial action. Examples of conduct that workers often display during industrial action include the trashing of cities, stoning of vehicles, vandalising property, forming picket lines at supermarkets, and preventing shoppers from doing business with their chosen businesses. ${ }^{3}$ Certain incidents that striking workers commit have shown that they can be a danger to society and non-striking workers. For example, during the truck drivers' strike in September 2012, a number of drivers who were not on strike were attacked and killed during the security workers' strike in 2006 and 2013, shops were looted, and the property of innocent bystanders, street vendors, spaza-shop owners and even the property of employers was damaged. In 2011, the Times newspaper reported that strikes by the South African

1 According to Snyman Criminal Law (2008) 260, a person is a perpetrator if -

"(a) his conduct, the circumstances in which it takes place (including, where relevant, a particular description with which he as a person must, according to the definition of a crime, comply) and the culpability with which it is carried out are such that he satisfies all the requirements for liability contained in the definition of the crime; or

(b) although his own conduct does not comply with that required in the definition of the crime, he acted together with one or more persons and the conduct required for a conviction is imputed or attributed to him by virtue of the principles relating to common purpose."

S v Mdlongwa 2010 (2) SACR 419 (SCA).

3 Jansen "Security Strike Violence: Union Leadership Found Wanting" 200630 South African Labour Bulletin 18. 
Municipal Workers Union (SAMWU) wreaked havoc across the country, with workers tipping over rubbish bins, trashing business centres and intimidating non-strikers.

Damage is also caused to the environment and could lead to health hazards. The non-collection of waste during strikes by municipal workers creates a habitat for unwanted vermin such as rats, and roads and cities become polluted. The burning of tyres by demonstrators pollutes the air and the environment, which could lead to serious diseases amongst the people.

The courts have also had an opportunity to hear cases where striking workers had caused damage or conducted themselves contrary to a peaceful picket or protest. In Kapesi v Premier Foods Ltd t/a Blue Ribbon Salt River ${ }^{5}$ several incidents of violence were committed during a strike. Non-strikers were harassed and intimidated, vehicles were damaged, a female non-striker was dragged from her home at night and assaulted with pangas and sjamboks. An interdict was obtained at the Labour Court but was ignored by strikers and nobody was sued for contempt of court. In Pikitup Johannesburg (Pty) Ltd (Pikitup) v South African Municipal Workers Union (SAMWU), ${ }^{6}$ it was observed that a large crowd of people wearing SAMWU T-shirts and hats stationed themselves outside the court during a hearing against members of the union who were accused of having committed violent acts such as destruction of concrete rubbish bins and strewn the content onto the streets and the rubbish bins were thrown across the road. They also dragged the tree trunk into the street, making the street inaccessible to road users. ${ }^{7}$

In In2Food (Pty) Ltd $v$ Food and Allied Workers Union, ${ }^{8}$ the striking workers acted contrary to picketing rules. They carried weapons, moved to the main road, stopped vehicles and removed commuters from public transport and prevented entrance into the workplace. ${ }^{9}$ The employer approached the court for an interdict against the union and individual strikers and such interdict was granted. However, despite the interdict, the violent strike continued.

Under these conditions, no one seems to be willing to take responsibility for these consequences, including the workers themselves. The general rule is that a person who committed the unlawful act should be held responsible for the consequences of his or her conduct. ${ }^{10}$ If a person has committed a criminal act, criminal law and criminal procedure will apply to his or her case. This contribution will, however, not investigate remedial actions in terms of the criminal law, but will investigate remedial actions available to victims of damage caused by industrial action in terms of the labour law.

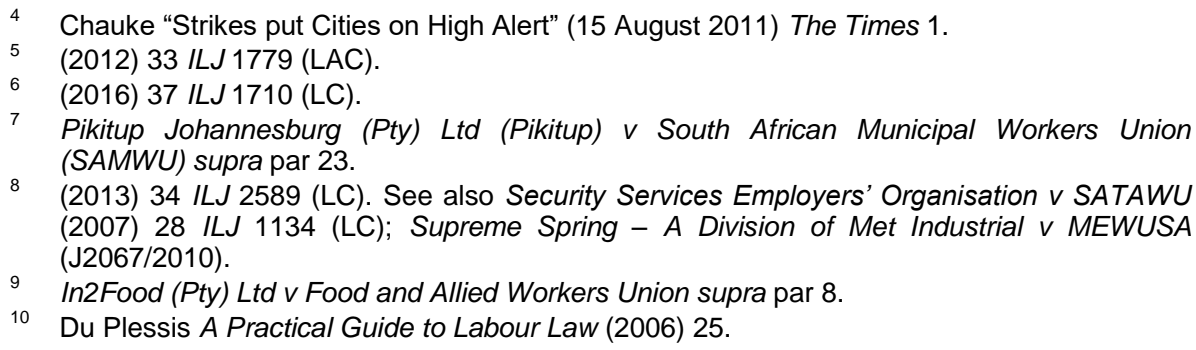


The article argues that even if the nature of the conduct of employees is collective, it is still necessary that the actual wrongdoer be identified to allow him or her opportunity to face the consequences of his or her conduct. This can be made possible through the use of electronic devices such as CCTV cameras.

\section{THE IMPORTANCE OF USING CCTV CAMERAS DURING COLLECTIVE ACTION}

The CCTV cameras are the most common form of surveillance systems used that record both the sound and image of an incident as and when it takes place and consequently, both the face and voice could potentially link the suspect to the unlawful act. ${ }^{11}$ The CCTV cameras can be installed in any place, whether private or public, and serve a variety of purposes. For example, those placed in towns and cities, allow law enforcement officers to monitor criminal activities, ${ }^{12}$ while those hidden in stores help to protect businesses against shoplifting. ${ }^{13}$

In some instances, the use of video footage has resulted in the dismissal of employees for misconduct. In Woolworths (Pty) Ltd $v$ Commission for Conciliation, Mediation and Arbitration, ${ }^{14}$ the employee was dismissed after having been captured on camera stealing in the store. In the context of strikes or conduct in contemplation or in furtherance of a strike, and consequent damage caused, CCTV footage could help to identify the actual perpetrator(s). Such use will greatly increase the success of holding individual perpetrators liable for the loss suffered during a picket or protest action. ${ }^{15}$ In $S \vee$ Mdlongwa, the accused were convicted of robbing the Natal Building Society (NBS) Bank in Dundee. The evidence against them was to a large extent, based on information obtained from video footage, which had unmistakably identified them. In the video footage, the accused were seen participating in the robbery. One of the accused denied that he was the person depicted in the footage. The court held that there was no reason to reject the authenticity of the video footage downloaded from the surveillance cameras. ${ }^{16}$

Video cameras can also serve as a deterrent to picketers or protesters not to engage in unlawful behaviour as they may realise that they will be identified and penalised for their conduct if captured by a CCTV camera. If their involvement in the commission of the unlawful act(s) is proved through video footage evidence, picketers or protesters may be reluctant to

11 Ibid.

12 Savides "Shouting Cameras Stun the Bad Guys" 25 November 2012 Sunday Times 6. The media reported that "municipal bosses in Pietermaritzburg have given the city's closed circuit television cameras a wide voice for yelling at those breaking the law or even thinking of doing so. Cameras in the KwaZulu-Natal capital have been mounted with megaphonelike speakers that allow control room operators to berate people for littering, vandalism or fighting; and suspected pickpockets are often warned that they are being watched".

13 See $S$ v Mdlongwa supra.

14 (2011) 32 ILJ 2455 (LAC).

15 Botes "Ham-fisted leadership and out-dated revolutionary rhetoric" 2011 Without Prejudice 7.

$16 \quad S$ v Mdlongwa supra par 23. 
participate in the commission of unlawful acts in the future. Although this is not guaranteed, a strike or picket is more likely to proceed without damage to property and without violence where video cameras are installed, and should remain peaceful as required by law. ${ }^{17}$

However, CCTV cameras will assist in the identification of the actual perpetrator(s) if such cameras are already installed in places where a picket or protest takes place. If CCTV cameras are not installed in a place by the time workers go on strike, it will be difficult to identify the actual perpetrator(s) and thus will be difficult for the victims to institute claims for compensation for damage caused.

Case law has also insisted on the need to identify the actual perpetrators of unlawful acts. In Ekurhuleni Metropolitan Municipality $v$ South African Municipal Workers Union (SAMWU), ${ }^{18}$ a large number of essential service employees had joined a picket convened by SAMWU. The behaviour of many went well beyond the bounds of legitimate picketing. Vehicles were damaged, non-striking employees assaulted, an electricity substation and water pipes sabotaged, sewage permitted to flood the streets and garbage were strewn about. The court, per Revelas J, referring to Woolworths (Pty) $L t d v$ SACCAWU ${ }^{19}$ held that:

"The Labour Court has always been, and probably always will be, sympathetic to employers in a situation where violence has erupted during a strike. It is against such behaviour that the court would readily grant interdicts. However, there should be some limitation to the granting of such interdicts in situations where the respondents are not properly identified. The court should always take into account what attempts have been made to identify persons against whom it issues such orders ... even if just a few names were put forward, would have been in a position to grant such an interdict, in the knowledge that the order is directed against at least some specific individuals who have been shown to behave in ways consistent with the allegations in the founding affidavit."

In Mondi Paper (a Division of Mondi Ltd) v Paper Printing Wood and Allied Workers Union, ${ }^{20}$ the applicant employer was not able to identify individual employees nor was he able to link them to the alleged acts of violence, except for eyewitnesses. The court refused to interdict the picket because the perpetrators could not be precisely identified. The court stated that the granting of an interdict without identifiable perpetrators would create the danger of extending the interdict to innocent and non-participating employees. that:

In Ex parte Consolidated Fine Spinners and Weavers $L t d{ }^{21}$ the court held

"The inability of the applicants to identify the perpetrators does not afford any justification in law for granting an order against a number of persons including persons against whom no cause of action has been established. The practical exigencies of the situation which have been eloquently and persuasively

\footnotetext{
S 17 of the Constitution and s 69(1) of the Labour Relations Act 66 of 1995.

[2011] 5 BLLR 516 (LC).

(2006) 27 ILJ 1234 (LC) 1236.

(1997) 18 ILJ 84 (D) 92.

(1987) 8 ILJ 97 (D).
} 
described by counsel for the applicants also does not afford justification for such course, no matter how desirable it may appear to be."

Even though CCTV cameras are a trusted form of modern technology and yields reliable images that can be used to identify perpetrators of unlawful acts, there are instances, where such footage had failed to identify the actual perpetrator(s) and the court consequently could not hold anyone liable. This was the case in Woolworths (Pty) Ltd v SA Commercial Catering and Allied Workers Union. ${ }^{23}$ The applicant employer applied for an interdict restraining the union and its members from intimidating, assaulting, harassing or in any other way interfering with the applicant's business, its employees and clients. The union denied any form of intimidation or unlawful conduct of its members. The applicant produced a video recording showing a group of people, some of whom carried sticks, preventing a truck from entering the applicant's premises. Another video showed a group of about 60 people being arrested by police. The court held that at least a certain measure of identification of the actual perpetrators should be made because granting a "blanket" court order, covering a whole range of the applicant's stores and employees, without attempting to identify persons, would be wrong. ${ }^{24}$

\section{The admissibility of video footage evidence}

As far as the admissibility of video footage evidence is concerned, the author argues that there are three matters that have to be looked at, namely: the relevance of video footage evidence, its authenticity, and the need for expert witnesses to corroborate such evidence.

As a general rule, no evidence regarding any fact, matter or thing is admissible if it is immaterial or irrelevant to the issue to be decided. ${ }^{25}$ It is also an accepted principle of law that "all facts of sufficient probative force are relevant and admissible unless their reception is prohibited by an exclusionary rule." 26 Thus evidence, for example, which is excluded because it is hearsay, may have a strong logical relevance to an issue, it may also be the best available evidence, but inadmissible. ${ }^{27}$ This means that not any video footage evidence is acceptable in court or similar structure, but such evidence must be relevant to the issue, which is the subject of a discussion.

In an attempt to identify actual perpetrators of riot damage during industrial action, video footage evidence will have to be used with caution as

22 Ex parte Consolidated Fine Spinners and Weavers Ltd supra par 19. See also Mondi Paper (a Division of Mondi Ltd) v Paper Printing Wood and Allied Workers Union supra 91H-I; Great North Transport (Pty) Ltd v TAWU [1998] 6 BLLR 98 (LC) par 21-29; Polyoak (Pty) Ltd v Chemical Workers Industrial Union (1999) 20 ILJ 392 (LC); Mkhondo Municipality v SA Municipal Workers Union (2006) 27 ILJ 1175 (LC) par 24

23 Supra.

24 Woolworths (Pty) Ltd v SACCAWU supra par 7.

25 S 2 of the Civil Proceedings Act 25 of 1965; s 21 of the Criminal Procedure Act 51 of 1977.

26 In $S v$ Boesman 1990 (2) SACR 389 (E) it was held that "the court has an overall discretion, based on public policy, to exclude evidence which would otherwise be admissible". See also $S$ v Jontjie 1992 (1) SACR 24 (SECL); Shell SA (Edms) BPK v Voorsitter Dorperaad van die Oranje-Vrystaat 1992 (1) SA 906 (O).

27 Schmidt and Zeffert Evidence (1997) 4. See also $R v$ Shaube-Kuffler 1969 (2) SA 40 (RA) 50. 
it could have dire consequences for employees whose fate could be decided by its use. The most important aspect when video footage evidence is considered, is its reliability. Video footage evidence will be reliable if it is authentic. $^{28}$ For recorded evidence to be authentic, certain requirements have to be met. These requirements were developed in $S v$ Singh where it was held that a video tape must contain the original recordings; and that there has to be no reasonable possibility of interference with the recording. ${ }^{29}$ In $S v$ Ramgobin, ${ }^{30}$ the court had to decide whether certain audio and video recordings were admissible as evidence against the accused person. The court considered the requirements laid down in $S \vee S i n g h$ and held that these were not exhaustive. ${ }^{31}$ The court held that it was also necessary to prove that the recordings related to the occasion to which it was alleged to relate and identify wrongdoers. ${ }^{32}$

However, a different conclusion was reached in the case of $S v$ Baleka ${ }^{33}$ where the court held that it was not a requirement that the authenticity of video footage evidence be first established before it is admitted in court. The court drew a distinction between authenticity and admissibility. The judge held that originality affects admissibility while authenticity does not. ${ }^{34}$ This means that if the evidence is reliable, it will be useful for providing an unbiased depiction of the detail and context in which the wrongful act was committed. ${ }^{35}$ It has been argued that video footage that is reliable can provide evidence that is more credible than that of eyewitnesses because it provides an unbiased account of the events since a tape, unlike a witness, cannot lie or forget detail. ${ }^{36}$ Those who have used the footage in trials report it to be the most powerful and effective evidence. ${ }^{37}$

In $S v$ Pistorius, ${ }^{38}$ the accused, Mr Pistorius, was charged with the murder of his girlfriend. The accused denied killing his girlfriend intentionally, arguing that it was a mistake. A number of witnesses were called by both the state and the defence. The court rejected the evidence of witnesses choosing to rely mostly on the evidence obtained via technology, for example, phone calls. In rejecting the evidence of witnesses, the judge said:

"Human beings are fallible and they depend on memories which failed over time. [t]his court is in a fortunate position in that it has objective evidence in

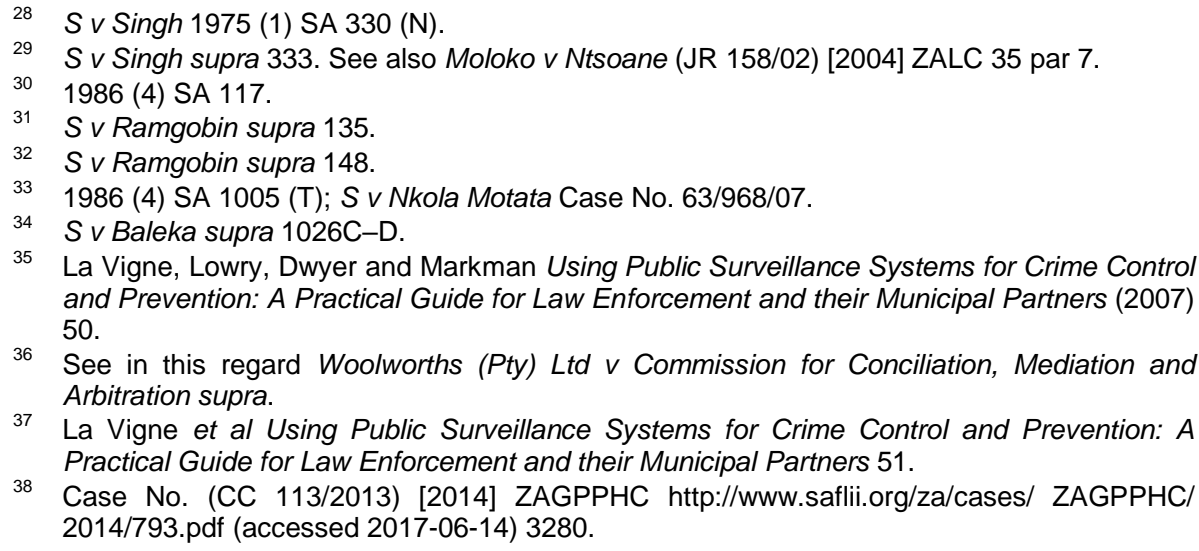

36 See in this regard Woolworths (Pty) Ltd $v$ Commission for Conciliation, Mediation and Arbitration supra.

37 La Vigne et al Using Public Surveillance Systems for Crime Control and Prevention: $A$ Practical Guide for Law Enforcement and their Municipal Partners 51.

38 Case No. (CC 113/2013) [2014] ZAGPPHC http://www.saflii.org/za/cases/ ZAGPPHC/ 2014/793.pdf (accessed 2017-06-14) 3280. 
the form of technology which is more reliable than human perception and human memory and against which all the other evidence can be tested."

Foreign courts have also commented on the usefulness of video footage during court proceedings. British courts, for example, have allowed CCTV footage as evidence. In $R \vee$ Maqsud Ali; $R \vee$ Ashiqi Hussain, ${ }^{40}$ the Supreme Court of Appeal held:

"[i]t does appear to this Court wrong to deny the law of evidence advantages gained by new techniques and new devices, provided the accuracy of the recording can be proved and the voices properly identified; provided also that the evidence is relevant and otherwise admissible."

Although video footage evidence can help corroborate the evidence of witnesses, video footage evidence itself has to be corroborated. Where the accuracy of a video recording is not clearly established, it is not safe to rely on it in the absence of corroborating evidence. ${ }^{42}$ Such evidence cannot be introduced independently. There must be a witness to the event purportedly recorded on the tape who testifies that it accurately portrays that event. ${ }^{43}$ In $S v$ Ramgobin, the court did not object to a witness being asked whether he or she recognised a scene or a person in a photograph, even if he or she had not taken the photograph, or had not been present when it was taken, or even if the origin of the photograph was unknown. ${ }^{44}$ If, however, the witness said he or she did not recognise any person or scene in the photograph, such evidence will not be admissible in the absence of proof that it was what it purported to be.

Recorded evidence must be identified as true representations of the objects and persons which they purport to represent. If they do so, such evidence can be said to be real evidence. ${ }^{45}$ Real evidence refers to things that are examined by the court as means of proof. ${ }^{46}$ In $S \vee$ Mdlongwa, ${ }^{47}$ the court held, after the appellants had questioned the originality and admissibility of the video footage presented in court, that "there can be no doubt that the video footage was original and therefore constituted real evidence." This principle was also confirmed in $S$ v Mpumlo, ${ }^{48}$ where it was stated that a video film was real evidence, provided it was relevant and admissible as evidence in court.

The use of video footage evidence may sometimes be rejected if it cannot be said that its use will serve the interests of justice. In Moloko $v$ Commissioner Diale, ${ }^{49}$ an employee was dismissed after being found by the arbitrator guilty of assaulting one of the employer's customers. The only evidence that was available before the arbitrator and which led to the

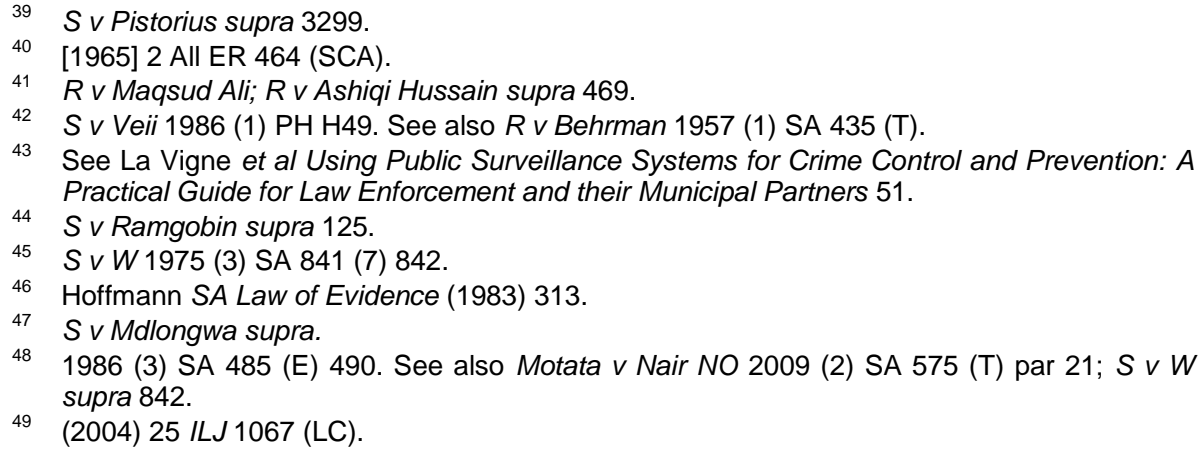


employee's conviction was the unsworn statement prepared by the complainant and video footage of the incident. The decision was appealed to the Labour Court. After repeated viewing of the video footage in various video playing machines, the Labour Court concluded that the recording was of such poor quality that it was difficult to recognise an assault on any person and it was, therefore, dangerous for the courts to rely on such evidence. ${ }^{50}$ It was held that the arbitrator erred in accepting such evidence. ${ }^{5}$ The arbitration award was set aside.

\section{Video footage and hearsay evidence}

Since video footage captures both the sound and image of incidents as they happen, it has to comply with the evidential rules applicable to both audio and visual recordings. The basic rule is that "hearsay evidence" is not admissible. "Hearsay evidence" is defined as "evidence, whether oral or in writing, the probative value of which depends on the credibility of any person other than the person giving such evidence.".52

Notwithstanding the general rule that hearsay evidence is not accepted in court, exceptions may arise. In Food and Allied Workers Union obo Kapesi v Premier Foods Ltd t/a Blue Ribbon Salt River, ${ }^{53}$ the question that the court had to answer was whether the recorded evidence of one of the strikers who turned witness for the employer could be relied upon to identify the perpetrators and to prove their guilt. It was common knowledge that the employees on strike attacked non-striking employees and management, petrol-bombed houses and vehicles, that kidnapping and assault occurred, and that at least one murder was committed. As an exception to the general rule, the court held that hearsay evidence could be accepted if the interests of justice required it.

The most common form of hearsay evidence acceptable in court is where such evidence is adduced by a witness who possesses certain knowledge and skill in the relevant field, the so called expert witness. ${ }^{54}$ Such a witness must be well qualified in his or her field of knowledge in order to satisfy the court that he or she possesses sufficient skills, training and experience to assist the court. ${ }^{55}$ There is no single criterion that is used to determine what an expert knowledge is. In addition to educational qualifications, various factors are, however, taken into account to determine whether the person is an expert in the field. These include skills, training and experience. The "skill, training or experience" required of an expert witness is an elastic concept as such knowledge might have been obtained through theoretical or practical experience. ${ }^{56}$ The expert's qualifications must be measured against

\footnotetext{
Moloko v Commissioner Diale supra par 10.

Moloko $v$ Commissioner Diale supra par 11.

S 1 of the Law of Evidence Amendment Act 45 of 1988. See also $S v$ Ramabele (1996) (1) SACR 639 (A) 469.

53 (2010) 31 ILJ 1654 (LC).

54 This is one of the acceptable exceptions in terms of $\mathrm{s} 3$ of the Law of Evidence Amendment Act.

55 Menday v Protea Assurance Co Ltd 1976 (1) SA 565 (E) 579; Mohamed v Shaik 1978 (4) SA $523(\mathrm{~N})$

56 Schmidt and Zeffert Evidence 30.
} 
the evidence he or she has to give in order to determine whether the qualifications or experience are sufficient to enable him or her to give that expert evidence.

The opinion of an expert is admissible only if it is relevant to the matter before the court. The court can rely on the opinion of an expert witness if his or her skill, training or experience enables him or her to materially assist the court on matters to which the court does not usually have the necessary expertise to make a decision. ${ }^{58}$ The expert will assist the court with his or her expertise.$^{59}$ The court must be satisfied that the opinion of the expert witness has a logical basis, in other words, the expert has considered the risks and benefits and has reached a defensible conclusion. ${ }^{60}$

The principles that govern the admissibility of expert opinion were listed in Holtzhauzen $v$ Roodt ${ }^{61}$ where the court held that:

"Firstly, the witness must be called to give evidence on matters calling for specialised skill;

Secondly, we are accustomed to receiving the evidence of psychologists and psychiatrists, particularly in our criminal court. However, we should not elevate the expertise of the witness to such heights that we lose sight of the court's own capabilities and responsibilities;

Thirdly, the witness must be a qualified expert;

Fourthly, the facts upon which the expert opinion is based must be proved by admissible evidence. These facts are either within the personal knowledge of the expert or on the basis of facts proved by others.

Fifthly, the guidance offered by the expert must be sufficiently relevant to the matter in issue which is to be determined by the court; and

Finally, the opinion evidence must not usurp the function of the court. The witness is not permitted to give opinion on the legal or general merits of the case."

57 S v Nagutuuala 1974 (2) SA 165 (SWA) 167. See further $R v$ Silverlock 1894 (2) QB 766; United States Shipping Board $v$ The Ship St Albans 1931 AC 632; S v Kimimbi 1963 (3) SA 250 (C) 22; S v Bertrand 1975 (4) SA 142 (C) 149. Sometimes technical or professional training or practical experience has been regarded as sine qua non, sometimes not. It all depends on practical considerations and the nature of the evidence lead. Thus the evidence of a chemist with inadequate practical experience was rejected in Van Heerden $v$ A Pulp and Paper Industries Ltd 1945 (2) PH J14 (W). The modern trend is to admit the opinion of foreign lawyers on foreign law, even where they are deficient in professional practice, if they are able to assist the court: Cooper-King v Cooper-King 1900 65; Brailey $v$ Rhodesia Consolidated Ltd 1910 (2) Ch 295 102-103; Barford v Barford and McLeod 1918 P 140; Ex parte Hiddingh's Goods of Bonelli 1875 (1) 69. See also The Sussex Peerage 1844 (11) C and F 85 117-132; 8 ER 1043 1047-1053; Hulscher v Voorschotkas voor Zuid Africa 1908 TS 542 .

58 See Coopers (SA) (Pty) Ltd v Deutsche Gesellschaft fur Schadlingsbekamfung MBH 1976 (3) SA 352 (A) 370.

59 See Schneider NO v AA 2010 (5) SA 203 (WCC).

60 See Michael v Linksfield Park Clinic (Pty) Ltd 2001 (3) SA 1188 (SCA) par 37. The same approach has been followed by the English Courts; see in this regard, Ballitho $v$ City and Hackney Health Authority 1998 AC 232 (HL). An example of an instance where the evidence of an expert witness was scrutinised by the court, and found to have significant problems and rejected for lack of credibility and expertise can be found in the judgment of Davis $\mathrm{J}$ in Schneider NO v AA supra 213. See also Minister van Veiligheid and Sekuriteit $v$ Geldenhuys 2004 (1) SA 515 (SCA) par 8; Representative of Lloyds v Classic Sailing Adventures 2010 (5) SA 90 (SCA) par 60.

611997 (4) SA 766 (WLD) 772-773. 
In the case of visual recordings, the evidence of an expert will be required to explain the workings and reliability of the device. ${ }^{62}$ If images of striking workers were captured by a reliable camera and/or corroborated by a witness, identify the actual perpetrator, an action could be taken against the person as identified through CCTV obtained evidence.

\section{REMEDIES AVAILABLE TO VICTIMS}

Once the perpetrator(s) of unlawful conduct has been identified, the question that arises is what recourse is available to the victims of strike misconduct? The author submits that since this is a labour relation's matter, the remedies can be sought from the Labour Relations Act ${ }^{63}$ (LRA). The LRA is clear on the consequences of protected and unprotected strikes or conduct in furtherance thereof. It makes provision for immunity from civil prosecution against employees who participated in a protected strike. ${ }^{64}$ The employer cannot take legal action against his or her employees for the mere reason that they participated in a protected strike or that they are in breach of the contract of employment. ${ }^{65}$

The LRA does not, however, tolerate conduct that is contrary to law. It states that the immunity offered to a protected strike or conduct in contemplation or in furtherance thereof, falls away if committed during a protected strike but it is an offence. ${ }^{66}$ This paves the way for the prosecution of these people on the grounds of misconduct. The LRA makes provision for remedies that the victims of such conduct could use where there is damage to their property or to themselves. These remedies are an order for an interdict, a claim for just and equitable compensation, and dismissal. ${ }^{67}$ Only a claim for compensation and dismissal is discussed with the former being deferred to Part 2 of this contribution.

\section{Just and equitable compensation}

The LRA refers to "just and equitable compensation" as one of the remedies available to the victims of the unprotected strike. ${ }^{68}$ The section allows any person who can prove that he or she suffered loss and such loss is

\footnotetext{
62 S v Mutle 1970 (4) SA 535 (T); S v Mthimkhulu 1975 (4) SA 759 (A). Unless there is a statutory presumption of a device's accuracy such as the one created by $s 212(10)(a)$ of the Criminal Procedure Act 51 of 1977, expert evidence is still necessary in South Africa to prove the workings and reliability of speed testing devices such as gatsometers, $S V$ Margalis 1964 (4) SA 579 (T); S v Du Plessis 1966 (1) SA 607 (C); R v Harvey 1969 (2) SA 193 (RA); S v Dawson 1966 (1) SA 259 (N); S v Sabotker 1970 (1) SA 206 (C); S v Sneddon 1970 (4) SA 241 (T); S v Hengst 1975 (2) SA 91 (SWA); National Union of Mineworkers v CCMA (2012) 33 ILJ 1898 (LC); Rambar Construction (Pty) Ltd t/a Rixi Taxi v CCMA (2012) 33 ILJ 1911 (LC).

63 Act 66 of 1995.

$64 \mathrm{~S} 67(8)$ of the LRA.

$65 \mathrm{~S} 187(1)(\mathrm{a})$ of the LRA.

66 S7(8) of the LRA.

$67 \mathrm{~S} 68(1)$ and (5) of the LRA.

$68 \mathrm{~S} 68(1)(\mathrm{b})$ of the LRA.
} 
attributable to the conduct of employees on strike. ${ }^{69}$ The LRA does not define or explain the meaning of "just and equitable" in the context of loss suffered as a result of the conduct of participants in an unprotected strike. Du Toit submits that the effect of section $68(1)$ is to create a sui generis cause of action. ${ }^{70}$ Unlike the position at common law, the plaintiffs are not entitled to the full measure of their damage but only to compensation that is just and equitable. ${ }^{71}$ This means that the Labour Court has to exercise discretion when determining what is just and equitable. In exercising its discretion, the Labour Court must take the following into account:

"whether

- attempts were made to comply with the provisions of this Chapter and

the extent of those attempts

- the strike or lock-out or conduct was premeditated

- the strike or lock-out or conduct was in response to unjustified conduct by another party to the dispute; and

- there was compliance with an order granted in terms of paragraph (a);

- the interests of orderly collective bargaining;

- the duration of the strike or lock-out; and

- the financial position of the employer, trade union or employees respectively."

In Rustenburg Platinum Mines Ltd $v$ Mouthpiece Workers Union, ${ }^{73}$ the court held that the words "just and equitable" mean no more than that compensation awarded must be fair. ${ }^{74}$

Claims for compensation may involve big sums of money and the question is whether an employee found to have committed an unlawful act will be able to pay such compensation. The damage that is normally caused by protesters amounts to millions of rands and it will be difficult to claim such an amount from an employee who is, often, penniless. In Rustenburg Platinum Mines Ltd $v$ Mouthpiece Workers Union, ${ }^{75}$ the applicant had claimed an amount of R15 million from the union for losses suffered as a result of a strike convened by the union. In Algoa Bus Company $v$ SATAWU ${ }^{76}$ the unions went on an unprotected strike which affected the respondent's transport operations on most of its routes. The applicant quantified the loss caused by the strike as R1.4 million. It is unlikely that an employee can pay these sums of money for damage caused by a strike or conduct in contemplation or in furtherance of a strike.

The author argues that the union should not be excluded when these claims are made. There are reasons for this suggestion although not discussed in detail in this part of the two contributions on the subject. Firstly, in terms of the solvency or deeper pocket theory of vicarious liability, the union should take liability because it is in a better financial position

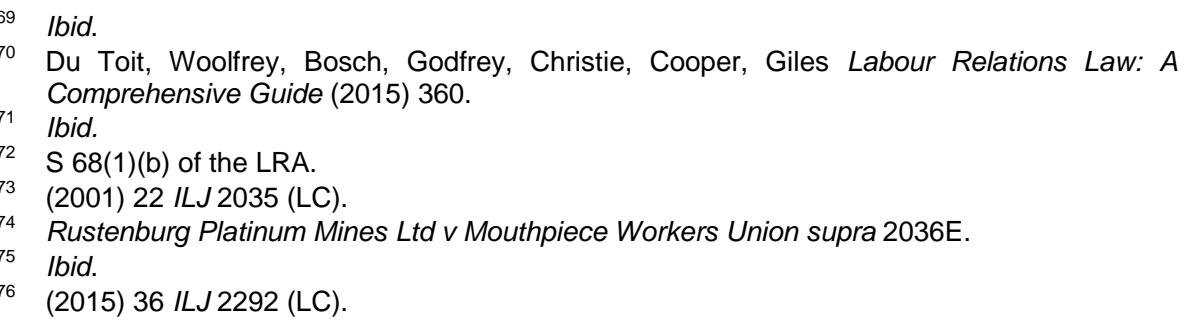


compared to an individual member. ${ }^{77}$ Secondly, by authorising a strike or picket, the union creates the risk of damage to third parties if one bears in mind the nature of the industrial action in the Republic which is often violent. Thirdly, unions as well members have a constitutional duty to keep pickets and protest action peacefully. ${ }^{78}$

So, if the action is not peaceful, both the convening union and the member(s) as identified through video footage evidence should be held liable for the damage caused. ${ }^{79}$ Part 2 of this series digs deep into the liability of a union for the conduct of its members. The author argues that the current social, political and economic considerations favour the development of vicarious liability to apply to trade union member relationship. The advantage of extending the application of vicarious liability in this way is to ensure that victims have someone to hold liable for the damage caused to them and their property and to get compensated. ${ }^{80}$

\section{Dismissal}

The LRA specifically lists misconduct as one of the valid grounds for taking the remedy of dismissal against an employee who committed the act. ${ }^{81}$ The remedy of dismissal is available if the victim of violent industrial action is an employer as he or she is at liberty to employ a person of his or her choice. ${ }^{82}$ $\mathrm{He}$ or she is also at liberty to dismiss an employee if there are good reasons for such dismissal. ${ }^{83}$ The commission of misconduct during industrial action, cannot be tolerated by employers. ${ }^{84}$ If an employee commits misconduct, the LRA empowers the employer to dismiss the employee(s). ${ }^{85}$ The question that arises is what type of conduct can constitute "misconduct"?

There is no comprehensive legal definition of the term "misconduct" to be found in statute or case law. ${ }^{86}$ The LRA only refers to inappropriate conduct as "misconduct" without defining the concept. ${ }^{87}$ It is, however, assumed that "misconduct" in labour relations refers to any conduct that is contrary to good conduct or contrary to law. ${ }^{88}$

The employer cannot just dismiss an employee for misconduct. He or she needs to prove the fairness of such dismissal and the appropriateness of the

\footnotetext{
See De Wilzem v De Regering van KwaZulu 19902 SA 915 (N) 921. See also Chataprops 16 (Pty) Ltd v Silberman 2009 (1) SA 265 (SCA) 282.

78 S 17 of the Constitution. See also Jumbo Products CC v NUMSA (1996) 17 ILJ 859 (W); NUMSA v Jumbo Products CC (1997) 18 ILJ 107 (W).

79 See SATAWU v Garvis (2012) 33 ILJ 1593 (CC).

80 The extension of vicarious liability to a trade union member relationship is discussed in Part 2 of this series.

$81 \mathrm{~S}$ 188(1)(a)(i) of the LRA read with item 2 of Schedule 8 of the Code of Good Practice: Dismissal.

82 However, the employer's choice is limited by s 43 of the Basic Conditions of Employment Act 75 of 1997, which prohibits the employment of children under the age of 15 years.

83 Sidumo v Rustenburg Platinum Mines Ltd [2007] 12 BLLR 1097 (CC) par 75.

84 CEPPWAWU v Metrofile (Pty) Ltd [2004] 2 BLLR 103 (LAC) 115G.

$85 \mathrm{~S} 68(5)$ of the LRA.

86 Grogan Dismissal (2014) 178.

87 Ibid.

${ }^{88}$ See Edcon Ltd v Pillemer NO [2010] 1 BLLR 1 (SCA).
} 
sanction for the conduct committed. ${ }^{89}$ Fairness comprehends that regard must be attributed not only to the position of the worker, but also to those of the employer, in order to make a balanced and equitable assessment. ${ }^{90}$

The onus is on the employer to prove that the employee has committed the act. If the employer cannot prove the case against the employee beyond a reasonable doubt, the matter should come to an end or dissolve. In Early Bird Farms (Pty) Ltd $v$ Mlambo, ${ }^{91}$ the court held that the employer does not have to prove with absolute certainty that the employee was guilty of misconduct but that proof on balance of probability was sufficient. ${ }^{92}$

In addition, it is not expected of the employer to change the charge of dismissal for misconduct into one for dismissal on the basis of operational requirements of the business because it is difficult to prove misconduct committed by the employee. ${ }^{93}$

Even if the LRA states that an act of misconduct can be a valid ground for dismissal, the circumstances of the case may determine otherwise, hence it is still necessary for the employer to prove misconduct as a reason for the sanction of dismissal. In Sidumo v Rustenburg Platinum Mines Ltd, ${ }^{94}$ it was held that the employer has the prerogative to dismiss an employee, but the determination of the fairness of such dismissal lies with the commissioner. ${ }^{95}$ The commissioner must consider a number of factors, including the importance of the rule that is alleged to have been breached, the harm caused by the employee's conduct, the impact of the employee's conduct on their relationship, the employee's length of service and the effect of dismissal on the employee.

The essence of a contract of employment is one of trust and confidence. ${ }^{97}$ If the element of trust has been breached, the chances that the parties will reconcile are diminished. In fact, where a material term of a contract of employment is breached, the result is that dismissal would be an appropriate sanction. The legal basis for dismissal for misconduct is that it is regarded as a breach of a material term of a contract of employment which could destroy the employment relationship. In Edcon Ltd v Pillemer NO, Mrs Reddy was in possession of a company car which was involved in an accident while driven by her son. Contrary to the company policy which required her to report the matter to the company, insurance and the police, she decided to secretly fix the damage. This was later discovered by the company. Mrs Reddy was then charged with failure to be honest, and act with integrity which was held

89 S 192 of the LRA provides that the employer bears the onus of proving on a balance of probabilities, that the dismissal was fair, both substantively and procedurally. See also Grogan Dismissal, Discrimination and Unfair Labour Practice (2005) 226; County Fair Foods v CCMA (1999) 20 ILJ 1701 (LAC) par 11.

90 NUMSA v Vetsak Co-operative Ltd 1996 (4) ILJ 455 (A).

91 [1997] 5 BLLR 541 (LAC).

92 Early Bird Farms (Pty) Ltd v Mlambo supra 544.

93 Food and Allied Workers Union obo Kapesi v Premier Foods Ltd t/a Blue River Salt River supra.

94 Supra.

95 Sidumo v Rustenburg Platinum Mines Ltd supra par 79. See also Nampak v Corrugated Wadeville $v$ Khoza [1999] 2 BLLR 108 (LAC) par 41.

96 Sidumo $v$ Rustenburg Platinum Mines Ltd supra par 79.

97 Council for Scientific and Industrial Research v Fijen [1996] 6 BLLR 685 (AD) 6911. 
to have affected the trust relationship between the company and the employee. ${ }^{98}$

However, the fact that employees commit misconduct and such misconduct is proved to be a valid reason for their dismissal, does not necessarily mean that they may be dismissed outright, but a fair procedure still needs to be followed prior to their dismissal. ${ }^{99}$

\section{Compliance with a fair procedure}

When an employer intends dismissing employees for misconduct, he or she is obliged by law to ensure that he or she follows a proper procedure. ${ }^{100}$ Section 188 requires that a decision to dismiss an employee for misconduct must be taken after following a fair procedure. ${ }^{101}$ This implies that the steps taken by an employer prior to dismissal must be fair. This will be achieved by taking into account the guidelines in the Code of Good Practice: Dismissal (hereinafter "the Code") in Schedule 8 of the LRA. ${ }^{102}$ The Code provides that:

"Any person who is determining whether a dismissal for misconduct is unfair should consider -

(a) whether or not the employee contravened a rule or standard regulating conduct in, or of relevance to, the workplace; and

(b) if a rule or standard was contravened, whether or not -

(i) the rule was a valid or reasonable rule or standard;

(ii) the employee was aware, or could be reasonably be expected to have been aware, of the rule or standard;

(iii) the rule or standard has been consistently applied by the employer; and

(iv) dismissal was an appropriate sanction for the contravention of the rule or standard.

Since misconduct is a statutory ground for dismissal, it is therefore, the most common justification for dismissal used by employers in South Africa. Bearing in mind that such cases of misconduct could too often, result in disciplinary hearings, the employer must prepare him/herself for this eventuality. In terms of the Code, the employer must adopt a policy or code of conduct that will regulate the conduct of employees inside or outside the workplace. The aim of the policy or code of conduct should be to curb against misconduct by employees. It is advisable that the policy should include a disciplinary code that involves a corrective discipline rather than a punitive act. ${ }^{104}$ In addition, because misconduct and its far-reaching implications are prevalent in many workplaces, there is nothing that prevents an employer from adopting a stringent provision in the policy that deals with serious misconduct.

98 Edcon Ltd v Pillemer NO supra par 5.

99 NUMSA v Badr Bop (Pty) Ltd (2003) 24 ILJ 305 (CC) 367. See also Edcon Ltd v Pillemer NO supra par 8 and 17.

$100 \mathrm{~S} 188(1)(\mathrm{b})$ and (2) of the LRA.

$101 \mathrm{~S} 188(1)(\mathrm{b})$ of the LRA.

102 Maropane $v$ Gillbeys Distillers and Vintners (Pty) Ltd (1998) 19 ILJ 635 (LC).

103 Item 7 of the Code.

104 Grogan Dismissal (2014) 182. 
The next question is whether the employee has breached the rule that regulates the conduct of employees. This will involve the determination of the conduct of the employee in relation to the rule or policy. For example, damage to property is, without a doubt, a contravention of the rule of good behaviour in the workplace. Employees should respect the property of their employer. Any damage arising out of the employee's conduct will attract disciplinary action. ${ }^{105}$ In this regard, the employer must prove the existence of a policy or code or rule that regulates the conduct of employees inside or outside the workplace. He or she must also prove that the employee has broken the policy or code of conduct. In proving the existence of a rule, a policy or code of conduct, employers are not expected to spell out every workplace rule in meticulous detail: it is sufficient to prove the existence and validity or lawfulness of the rule or code or policy. ${ }^{106}$

A serious misconduct is the one that can attract the sanction of dismissal. For example, in Woolworths (Pty) Ltd $v$ SACCAWU, it was held that where a company rule provided that till shortages or excesses of over R500 attracted the sanction of dismissal for a first offence, such rule is valid. ${ }^{107}$ The mere fact that the LRA makes misconduct one of the grounds for dismissal, does not mean that misconduct is always an appropriate sanction for dismissal. It is still necessary that the appropriateness of the remedy is determined. In establishing the appropriateness of the sanction, the presiding officer at the disciplinary proceedings is compelled to exercise his or her discretion in respect of the sanction reasonably, honestly and with due regard to the general principles of fairness. ${ }^{108}$ Du Plessis argues that for a misconduct to constitute an appropriate sanction it has to be serious. ${ }^{109}$ He further argues that misconduct would be serious to justify dismissal if it renders the continued relationship between employer and employee intolerable. ${ }^{110}$ In Nampak Corrugated Wadeville $v$ Khoza, it was held that:

"The determination of an appropriate sanction is a matter which is largely at the discretion of the employer. However, this discretion must be exercised with fairness. A court should, therefore, not lightly interfere with the sanction imposed by the employer unless the employer acted unfairly in imposing the sanction. The question is not whether the court would have imposed the sanction imposed by the employer, put whether in the circumstances of the case, the sanction was reasonable."

This means that in determining the fairness or otherwise of a decision to dismiss, the commissioner must bear in mind that there are various

105 Nampak v Golden Arrow Bus Service (1994) 15 ILJ 1113 (IC).

106 Free State Buying Association Ltd t/a Alpha Pharm v SACCAWU (1998) 19 ILJ 1481 (LC).

107 (2016) 37 ILJ 2831 (LAC) par 26.

108 Nampak Corrugated Wadeville $v$ Khoza (1999) 20 ILJ 578 (LAC). The court approved the approach adopted in Computicket $v$ Marcus NO (1999) 20 ILJ 342 (LC), in which it was said: "The question of sanction for misconduct is one on which reasonable people can readily differ. One person may consider that the dismissal is an appropriate sanction for an offence, another that something less, such as a warning, would be appropriate. There are obviously circumstances in which a reasonable person would naturally conclude that dismissal was the appropriate sanction, for example, if there has been theft of a significant amount of money, fraud or other untrustworthy conduct on the part of the employee."

109 Du Plessis and Fouche A Practical Guide to Labour Law (2012) 290.

110 Ibid. See also Sidumo v Rustenburg Platinum Mines Ltd supra par 33.

111 Nampak Corrugated Wadeville v Khoza supra par 33. 
sanctions that the employer can take in relation to the act committed. It is then the duty of the commission to establish whether the sanction taken is the appropriate one in relation to the circumstances before him or her. ${ }^{112}$ The employer must also prove that employees are aware of the existence of the rule or policy which regulates their conduct in the workplace as well as the consequences for failure to comply with the said rule or policy. ${ }^{113}$ Employees may be disciplined for contravening a rule only if they knew about its existence. There are various ways of making the rule or policy known to the employees. The rule can be displayed on notice boards using language spoken in the workplace. It can also be communicated by attaching it in the employees' contracts of employment. The rule or policy can be formalised in a collective agreement.

Therefore, if employees were seen, through video footage, causing damage to property, or intimidating people, their conduct will be judged against the rule or policy that regulates such conduct. Obviously, they will be acting contrary to the policy if they commit misconduct. The employer may be justified in taking the sanction of dismissal against them.

Once it has been established that the rule or policy does exist and employees have breached such rule or policy followed by dismissal, the question that arises is whether the employer has consistently applied the rule of policy. A distinction is made between historical and contemporaneous inconsistency. The employer must prove that the rule has been applied consistently in the past if employees have committed the same or similar misconduct. Historical inconsistency occurs when an employer has in the past not dismissed employees for committing the same or similar misconduct. However, if the employer has in the past tolerated such conduct, the dismissal will not be fair unless he or she can prove that he or she has reformed. ${ }^{114}$ Unfairness will flow from the employees' state of mind as the circumstance or past practice will reveal that they are unaware that such conduct would lead to dismissal.

The employer must also prove that all employees accused of committing the same or similar offences are dealt with in the same manner. ${ }^{115}$ This is referred to as contemporaneous inconsistency. It occurs when two or more employees engage in the same or similar conduct at roughly the same time, but only one of them is disciplined. In Henred Freuhaul Trailers (Pty) Ltd v NUMSA, ${ }^{116}$ Some 44 employees were dismissed after taking part in a nationwide strike along with 2000 employees from different branches. The reason for their dismissal was held to be a need to monitor the production in their plant with relative ease, whereas the effects of the strike action in other

12 Todd and Damant “Unfair Dismissal - Operational Requirements” 200425 ILJ 896907.

113 Hoechst (Pty) Ltd v CWU (1993) 14 ILJ 1449 (LAC); Saaiman v De Beers Consolidated Mines (Finsch Mines) (1995) 16 ILJ 1551 (IC).

114 Minister of Correctional Services v Mthembu NO (2006) 27 ILJ 2115 (LC).

115 SACCAWU $v$ Irvin and Johnson (Pty) Ltd (1999) 20 ILJ 2302 (LAC) 2313. See also Mabanina v Baldwins Steel [1999] 5 BLLR 453 (LAC); NUMSA v Steloy Stainless Precision Casting (Pty) Ltd [1995] 7 BLLR 87 (IC); NUM v Council for Mineral Technology (1998) 3 LCD 448 (D).

116 (1992) 13 ILJ 593 (LAC); NUMSA v Atlantis Forge (Pty) Ltd (2005) 26 ILJ 1984 (LC); Rustenburg Platinum Mines Limited (Bofoken Rasimone) Platinum Mine v CCMA (2007) 28 ILJ 408 (LC). 
plants were difficult to gauge. The Labour Appeal Court found their dismissal to be a totally arbitrary reason for selecting employees for dismissal.

To justify differential treatment of workers who committed similar offences, the employer must show that there was a valid reason for such differentiation. ${ }^{117}$ In CEPPWAWU $v$ Metrofile, ${ }^{118}$ the court found that the employees who had blockaded one branch of the company and who were not dismissed were guilty of worse behaviour than those who had done the same at another branch and were dismissed. ${ }^{119}$ The dismissed employees were reinstated.

If an individual is identified in video footage as the person who committed the unlawful act as was the case in Woolworths (Pty) Ltd v Commission for Conciliation, Mediation and Arbitration, ${ }^{120}$ the process of holding him or her liable must be fair, unbiased and in compliance with the law. To ensure fairness, the person who will be affected by the decision must be given the opportunity to present his or her side of the case before the decision is taken. If an employee or member of the union accused of committing an unlawful act is given this opportunity, a new turn of events may be uncovered which might change the direction of the disciplinary action.

\section{Opportunity to make representations}

Once a particular individual has been identified by way of video footage as the person responsible for the unlawful act(s), and the employer elects to deal with the employee in terms of 68(5) of the LRA, the employer must give the employee an opportunity to state his or her case in response. Section $68(8)$ of the LRA obliges the employer to follow the guidelines for a fair procedure in terms of schedule 8 of the Code of Good Practice: Dismissal.

The Code requires that an employee must be granted the opportunity to make representations during disciplinary action against him or her. ${ }^{121}$ This is especially true in the case of the striking workers, where the opportunity must be granted at the earliest opportunity. ${ }^{122}$ Not only should employees be given the opportunity to be heard, they must also be given reasonable and timeous notice to enable them to gather the necessary information they wish to present at the hearing. What constitutes a reasonable period of time will depend on the circumstances of each case. The more involved the issue, the longer the time period that will be required.

With regard to the employer's obligation to grant employees a predismissal hearing, the court in FAWU $v A B I,{ }^{123}$ held that it would have been sufficient for the employer to give each of the crewmen who assaulted

\footnotetext{
See NUMSA v Delta Motor Corporation (2002) 9 BLLR 817 (LAC).

122 MAN Truck and Bus SA (Pty) Ltd and United African Motor and Allied Workers Union (1991) 12 ILJ 181 (ARB) 192.

123 Food and Allied Workers Union v Amalgamated Beverage Industries (1994) 15 ILJ 630 (IC) 647.
} 
another employee, the opportunity to distance him- or herself from the assault. ${ }^{124}$ If an employee is afforded the opportunity to present his or her side of the story, the account of the events may prove to be different from what was originally believed, often to the advantage of the person accused and the possible dropping of the charges. A failure to grant this opportunity will seriously impair the procedural fairness of the action taken against the employee(s).

\section{CONCLUSION}

The use of CCTV cameras helps in the identification of perpetrators if such cameras are already installed in an area where misconduct takes place. During industrial action, the identification of actual perpetrators will serve to counter union denials that the people involved in the commission of such acts were not its members as the video footage might prove the opposite. The use of such technology could not only help to identify the actual perpetrator(s) but could also help to absolve innocent participants from liability for the wrongs committed by other people.

The author acknowledges, however, that challenges and difficulties do exist in our law at present, with regard to the use of CCTV cameras to identify individual members as the one who committed misconduct during the concerted action. A union representative may, for example, allege that the process of collective bargaining is undermined when employees who participate in industrial action are video-taped and disciplinary action taken against them. The employer has to prove that the union is not being disciplined for exercising its right to call industrial action and for its members to participate in it, but that it is disciplinary action solely for damaging conduct committed during industrial action. ${ }^{126}$

Once the actual perpetrator has been identified, the employer may take disciplinary action against him or her. The LRA makes provision for the remedy of dismissal if misconduct is committed during industrial action. ${ }^{127}$ Although misconduct is a recognised ground for dismissal as it breaches a material term of the contract of employment, it must be fair. The employer must prove that the trust relationship has broken down to the extent that it will be impossible to work together with the employee. In addition, he or she must follow a fair procedure that will allow the employee sufficient time to make representation. If these requirements are complying with, the dismissal of an employee for misconduct would be fair.

124 Food and Allied Workers Union v Amalgamated Beverage Industries supra 644B.

125 "Even if the action by the employees may have been unlawful, regard must be had to the fairness of the ensuing procedural steps and of the sanction which was meted out as a result of such procedure", NUMSA v Tek Corporation Ltd (1991) 12 ILJ 577 (LAC) 582.

126 Safcor Freight (Pty) Ltd t/a Panalpina v SA Freight and Dock Workers Union (2013) 34 ILJ 335 (LAC).

$127 \mathrm{~S} 68(5)$ of the LRA. 